\title{
Pollution Characteristics and Human Health Risks of Elements in Road Dust in Changchun, China
}

\author{
Na Li ${ }^{1,2, *}$, Weizheng Han ${ }^{3}$, Jie Tang ${ }^{1}$, Jianmin Bian ${ }^{1}$, Siyue Sun ${ }^{2}$ and Tiehong Song ${ }^{2}$ \\ 1 Key Laboratory of Groundwater Resources and Environment, Ministry of Education, Jilin University, \\ Changchun 130021, China; tangjie0724@163.com (J.T.); bianjianmin@126.com (J.B.) \\ 2 Key Laboratory of Songliao Aquatic Environment, Ministry of Education, Jilin Jianzhu University, \\ Changchun 130118, China; susiyue0626@126.com (S.S.); tiehongsong@ufl.edu (T.S.) \\ 3 Changchun Institute of Urban Planning \& Designing, Changchun 130031, China; blackhwz@163.com \\ * Correspondence: lina7768546@163.com
}

Received: 26 June 2018; Accepted: 20 August 2018; Published: 27 August 2018

\begin{abstract}
Road dust, which contains trace elements and certain organic matter that can be harmful to human health, plays an important role in atmospheric pollution. In this paper, concentrations of 16 elements in the road dust of Changchun, China were determined experimentally. A total of 100 samples were collected using plastic brushes and dustpans, and the elements were analyzed by an inductively coupled plasma optical emission spectrometer (ICP-OES). It was indicated that the elements could be divided into major and trace elements. The concentration of trace elements followed the trend: mercury $(\mathrm{Hg})>$ manganese $(\mathrm{Mn})>$ zinc $(\mathrm{Zn})>$ lead $(\mathrm{Pb})>$ chromium $(\mathrm{Cr})>\operatorname{copper}(\mathrm{Cu})>\operatorname{vanadium}(\mathrm{V})>\operatorname{arsenic}(\mathrm{As})>\operatorname{nickel}(\mathrm{Ni})>\operatorname{cobalt}(\mathrm{Co})>\operatorname{cadmium}(\mathrm{Cd})$. Contamination-level-assessment calculated by the geo-accumulation index $\left(\mathrm{I}_{\text {geo }}\right)$ showed that the pollution-level ranged from non-contaminated to extreme contamination, while the calculations of enrichment factor $(\mathrm{EF})$ showed that $\mathrm{EF}$ values exhibited a decreasing trend: $\mathrm{Cd}>\mathrm{Hg}>\mathrm{As}>\mathrm{Pb}>$ $\mathrm{Cu}>\mathrm{Co}>\mathrm{Zn}>\mathrm{Ni}>\mathrm{Cr}>\mathrm{V}>\mathrm{Mn}>\mathrm{Mg}>\mathrm{Fe}>\mathrm{Sr}>\mathrm{Ba}$. In our study, ingestion was the greatest exposure pathway for humans to intake trace elements by calculating the average daily dose (ADD) from three routes (ingestion, inhalation, and dermal contact). According to the health risk assessment results, the non-carcinogenic risks that human beings suffered from these elements were insignificant. Additionally, the hazard quotient $(\mathrm{HQ})$ values were approximately one-tenth in the case of children. Meanwhile, the total excess cancer risk (ECR) was also lower than the acceptable level $\left(10^{-6}-10^{-4}\right)$ for both adults and children.
\end{abstract}

Keywords: road dust; trace elements; enrich factor; average daily dose; cancer risk

\section{Introduction}

In recent decades, the rapidly growing economy of China has resulted in a dramatic change in human activities such as industrialization and urbanization [1-4]. As a result, serious environmental problems have emerged, especially air pollution, which has become one of the most significant environmental concerns of both the public and scientists for the past few decades. Researchers have analyzed atmospheric pollution sources such as coal combustion, vehicle emission, soil, construction, as well as road dust [5-7]. It is necessary to study the physical chemical properties of each source to obtain a more precise result of source analysis, such as element characteristics, organic component, polycyclic aromatic hydrocarbons (PAHs), polybrominated diphenyl ethers (PBDEs), and persistent organic pollutants (POPs) [8-11].

Heavy metal pollutants can enter the atmosphere and natural water systems through re-suspension and runoff, respectively [12-15]. Studies regarding the metal components of road dust have been 
conducted worldwide [16-20]. According to previous studies, the concentrations of elements in road dust are significantly different depending on land use, population diversity, human activities, vehicle situations, number of cars, commercial areas, park locations, etc. Furthermore, trace elements, especially heavy metals, may harm human health since they can enter the body through ingestion, inhalation, and dermal contact [21-24], and can even reach the lungs and alveoli. Lead ( $\mathrm{Pb}$ ), arsenic ( $\mathrm{As})$, nickel $(\mathrm{Ni})$, cadmium $(\mathrm{Cd})$, and chromium $(\mathrm{Cr})$, which are likely to cause cancer [25], have been frequently reported in high concentrations and may cause an elevated cancer risk in both adults and children.

Changchun city is the capital of Jilin Province located on the Northeast Plain of China. The city area covers over $3619.42 \mathrm{~km}^{2}$, and the population was roughly 3,280,898 in 2015, an increase from approximately 1,643,000 in 1980. The temperature is low in winter and the heating period can last from October to the following March. The dominant wind directions are SW and NE through the year. Industrial work makes up the most significant land uses in this city, followed by residential and commercial usage. Since the first motor factory was built in Changchun, the automobile industry has become the most developed economic activity in the area. In addition, metallurgy, medical, machines and electronic manufacturing play an active part in the economy of Changchun city. The number of motor vehicles reached 1 million in 2011 [26]. This technical change can cause severe atmospheric pollution due to intense human activities and long-term heating in winter. Many studies have reported the physical chemical characteristics of aerosols and source appointment. Studies have been reported characteristics of elements in road dust throughout the world, but no research has been published in the area of study. The article supports the references of source allocation in Northern China.

The main objectives of this paper were: (1) to obtain the metal element concentrations of road dust in Changchun city; (2) to calculate the geo-accumulation index; (3) to determine the enrichment factor; (4) to analyze the average exposure dose of elements; (5) to obtain the value of hazard quotient $(\mathrm{HQ})$ and hazard index (HI) for non-carcinogenic health risk; (6) to calculate the cancer risks of $\mathrm{Pb}, \mathrm{Ni}$, As, $\mathrm{Cr}$ and $\mathrm{Cd}$. The overall goals were to identify and evaluate the pollution levels of the different elements in a northeastern city in China and to establish a comprehensive method for geochemical data interpretation.

\section{Materials and Methods}

\subsection{Sample Collection}

One hundred road dust samples were collected from Changchun in June 2017 (Figure 1). The sampling was not conducted on rainy or windy days, and the ground was dry, which was at least seven days after any rainfall. At each site, samples were collected from the indurative ground, with each sample weight being $>100 \mathrm{~g}$, by using plastic brushes and dustpans, which were stored in self-sealing polyethylene bags and brought to the lab as soon as possible. After being air-dried, the collected road dust was sieved with $100 \mu \mathrm{m}$ nylon sieves to remove debris, hair, and leaves. The samples were measured by an inductively coupled plasma optical emission spectrometer (ICP-OES) and were stored at $-20{ }^{\circ} \mathrm{C}$ before analysis. Sixteen typical elements were chosen to be tested. These were iron $(\mathrm{Fe})$, manganese (Mn), $\mathrm{Cr}, \mathrm{Ni}, \mathrm{Cd}$, magnesium $(\mathrm{Mg})$, aluminum (Al), copper $(\mathrm{Cu})$, zinc $(\mathrm{Zn}), \mathrm{Pb}$, barium $(\mathrm{Ba})$, strontium (Sr), As, mercury ( $\mathrm{Hg})$, cobalt $(\mathrm{Co})$, and vanadium $(\mathrm{V})$. For the total concentrations, $0.1 \mathrm{~g}$ samples (three repeat parallel samples for each site) were measured on an electronic balance (Sartorius TE124S, Göttingen, Germany). Then, these were placed in Teflon tubes and digested using an $8 \mathrm{~mL}$ acid mixture $\left(\mathrm{V}_{\mathrm{HCl}}: \mathrm{V}_{\mathrm{HNO}_{3}}=1: 3\right)$. A microwave digestion apparatus (Topwave, Analytic Jena, Jena, Germany) was used to digest the samples, selecting the digestion program Soil EPA $3051\left(175^{\circ} \mathrm{C}\right.$, $10 \mathrm{~min}, 50^{\circ} \mathrm{C}, 22 \mathrm{~min}$ ). After cooling, the digested solutions were diverted to a volumetric flask and diluted to $50 \mathrm{~mL}$. All the metals were determined by inductively coupled plasma optical emission spectrometer (ICP-OES, Prodigy XP, Leeman, Hudson, NH, USA). The standard curve was accepted when the correlation coefficients were close to 1 . During the experimental process, ultra-pure water 
(electric resistivity: $18 \mathrm{M} \Omega \times \mathrm{cm}$ ) was used for the dilutions. The used containers were dipped in liquid acid ( $10 \% \mathrm{HNO}_{3}$ in volume) for $12 \mathrm{~h}$, then rinsed to avoid potential cross-contamination of the samples.

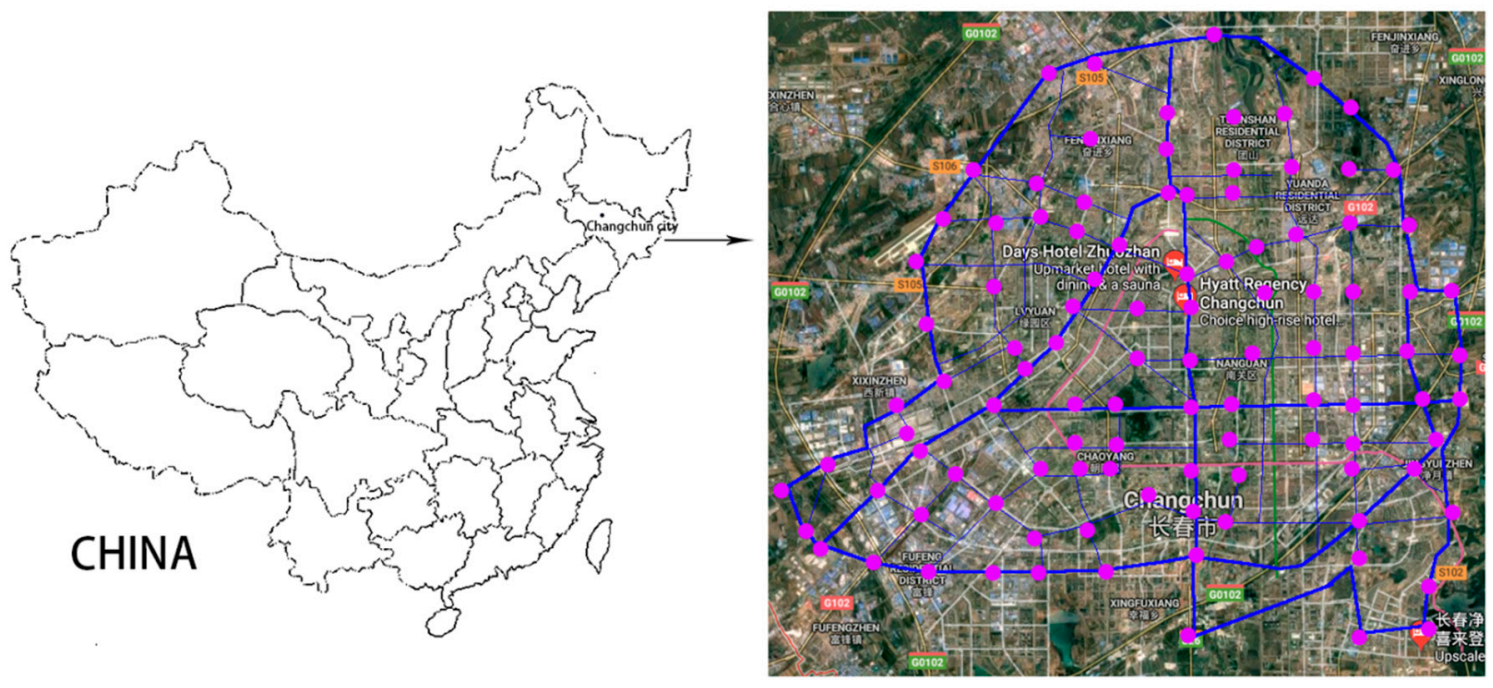

Figure 1. Sampling sites.

\subsection{Quality Assurance (QA) and Quality Control (QC)}

Quality assurance (QA) and quality control (QC) were evaluated using duplicates, method blanks, and state first-level conventional materials (GBW GSS-5). Each sample was tested three times, and the results were accepted if the repeat sample analysis error was below $5 \%$. The environmental procedures followed were by the Chinese Technical Specification for Soil Environmental Monitoring HJ/T 166-2004.

\subsection{Contaminant Level Assessment}

\subsubsection{Geo-Accumulation Index}

The geo-accumulation index $\left(\mathrm{I}_{\text {geo }}\right)$ assessment has been widely used to study metal enrichment by comparing each value of the trace elements to the crust concentration $[27,28]$. It was computed using the following equation:

$$
\mathrm{I}_{\text {geo }}=\log _{2} \frac{\mathrm{C}_{\mathrm{x}(\text { sample })}}{1.5 \times \mathrm{C}_{\mathrm{x}(\text { crust })}}
$$

$\mathrm{C}_{\mathrm{x} \text { (sample) }}$ and $\mathrm{C}_{\mathrm{x}(\mathrm{crust})}$ represent the concentrations of metal " $\mathrm{x}$ " for measuring and earth crust, respectively. Concerning the natural fluctuations and anthropogenic influence, the denominator must be multiplied by 1.5 . In general, $I_{\text {geo }}$ values $>1$ may imply that the metal can be impacted by anthropogenic sources, which can be divided into seven classes as listed in Table 1.

Table 1. Contamination categories.

\begin{tabular}{|c|c|c|c|c|}
\hline \multicolumn{3}{|c|}{ Geo-Accumulation Index } & \multicolumn{2}{|c|}{ Contamination Categories Based on EF Values } \\
\hline Class & $\mathrm{I}_{\mathrm{geo}}$ value & Contamination level & EF values & Contamination categories \\
\hline 0 & $\mathrm{I}_{\mathrm{geo}} \leq 0$ & Uncontaminated & $\mathrm{EF}<2$ & Deficiency to minimal enrichment \\
\hline 1 & $0<\mathrm{I}_{\text {geo }} \leq 1$ & Uncontaminated to moderately contaminated & $2<\mathrm{EF}<5$ & Moderate enrichment \\
\hline 2 & $1<\mathrm{I}_{\text {geo }} \leq 2$ & Moderately contaminated & $5<\mathrm{EF}<20$ & Significant enrichment \\
\hline 3 & $2<\mathrm{I}_{\text {geo }}<3$ & Moderately to heavily contaminated & $20<\mathrm{EF}<40$ & Very high enrichment \\
\hline 4 & $3<\mathrm{I}_{\text {geo }} \leq 4$ & Heavily contaminated & $\mathrm{EF}>40$ & Extremely high enrichment \\
\hline 5 & $4<\mathrm{I}_{\text {geo }} \leq 5$ & Heavily to extremely contaminated & & \\
\hline 6 & $\mathrm{I}_{\mathrm{geo}}>\overline{5}$ & Extremely contaminated & & \\
\hline
\end{tabular}




\subsubsection{Enrichment Factor}

The enrichment factor (EF) was selected to assess the enrichment and contamination levels of the elements [29]. EFs are calculated by the following formula:

$$
\mathrm{EF}=\left(\mathrm{C}_{\mathrm{n}} / \mathrm{C}_{\mathrm{Al}}\right)_{\mathrm{s}} /\left(\mathrm{C}_{\mathrm{n}} / \mathrm{C}_{\mathrm{Al}}\right)_{\mathrm{r}}
$$

$\left(\mathrm{C}_{\mathrm{n}} / \mathrm{C}_{\mathrm{Al}}\right)_{\mathrm{s}}$ is the ratio of the concentration of an element with that of $\mathrm{Al}$ at each sampling point, and $\left(\mathrm{C}_{\mathrm{n}} / \mathrm{C}_{\mathrm{Al}}\right)_{\mathrm{r}}$ is the same ratio of the background content in soils. The reference values can be selected as the Jilin Province background values. According to the EF values, five contamination levels were divided (Table 1).

\subsubsection{Exposure Dose}

Exposure assessment reflects the considerations identified in the problem formulation, including exposure dose and hazard identification [30]. It can be divided into three routes (oral, respiratory, and dermal paths) for chemical penetration into the human body [31]. Consequently, the exposure dose assessment can also be divided into three parts: ingestion, inhalation and dermal contact $[32,33]$, which can be calculated by the following equations:

$$
\begin{gathered}
\mathrm{ADD}_{\text {ing }}=\frac{\mathrm{C} \times \mathrm{CF} \times \mathrm{IR}_{\mathrm{S}} \times \mathrm{FI} \times \mathrm{EF} \times \mathrm{ED}}{\mathrm{BW} \times \mathrm{AT}} \\
\mathrm{ADD}_{\text {inh }}=\frac{\mathrm{C} \times \frac{1}{\mathrm{PEF}} \times \mathrm{IR}_{\mathrm{a}} \times \mathrm{ET} \times \mathrm{EF} \times \mathrm{ED}}{\mathrm{BW} \times \mathrm{AT}}=\frac{\mathrm{C} \times \mathrm{IR}_{\mathrm{a}} \times \mathrm{ET} \times \mathrm{EF} \times \mathrm{ED}}{\mathrm{PEF} \times \mathrm{BW} \times \mathrm{AT}} \\
\mathrm{ADD}_{\text {derm }} \begin{array}{c}
=\frac{\mathrm{DA} \mathrm{A}_{\text {event }} \times \mathrm{EF} \times \mathrm{ED} \times \mathrm{EV} \times \mathrm{SA}}{\mathrm{BW} \times \mathrm{AT}} \\
=\frac{\mathrm{C} \times \mathrm{CF} \times \mathrm{AF} \times \mathrm{ABS} \times \mathrm{AF} \times \mathrm{ED} \times \mathrm{EV} \times \mathrm{SA}}{\mathrm{BW} \times \mathrm{AT}}
\end{array}
\end{gathered}
$$

$\mathrm{ADD}_{\text {ing, }}, \mathrm{ADD}_{\text {inh, }}$, and $\mathrm{ADD}_{\text {derm }}$ represent the average daily exposure doses of metals via ingestion, inhalation, and dermal contact, respectively ( $\mathrm{mg} / \mathrm{kg} /$ day); $\mathrm{C}$ represents the concentration of metals in road dust $(\mathrm{mg} / \mathrm{kg}) ; \mathrm{CF}$ is the conversion factor $\left(10^{-6} \mathrm{~kg} / \mathrm{mg}\right)$; $\mathrm{IR}_{\mathrm{s}}$ represents the ingestion rate of receptors (mg/day); FI represents the fraction ingested from a contaminated source (unitless); EF represents the exposure frequency (days/year); ED represents the exposure duration (years); BW represents body weight $(\mathrm{kg})$; AT represents the averaging time (days), non-carcinogenic effects is ED $\times 365$ days/year, and carcinogenic effects is 70 years $\times 365$ days/year; $\mathbb{R}_{a}$ represents the inhalation rate for receptor $\left(\mathrm{m}^{3} / \mathrm{h}\right)$; PEF represents the particulate emission factor $\left(\mathrm{kg} / \mathrm{m}^{3}\right)$; ET represents the exposure time (hours/day), $\mathrm{DA}_{\text {event }}$ represents the absorbed dose per event $\left(\mathrm{mg} / \mathrm{cm}^{2} /\right.$ event), the calculation is $\mathrm{C} \times \mathrm{CF} \times \mathrm{AF} \times \mathrm{ABS}$; $\mathrm{AF}$ represents the adherence factor from road dust to skin ( $\mathrm{mg} / \mathrm{cm}^{2} / \mathrm{event}$ );

\begin{tabular}{|c|c|c|c|c|c|c|c|}
\hline Parm. & Unit & Class & Value & Parm. & Unit & Class & Value \\
\hline $\mathrm{IR}_{\mathrm{S}}$ & $\mathrm{mg} /$ day & $\begin{array}{l}\text { Adults } \\
\text { Children }\end{array}$ & $\begin{array}{l}30^{\mathrm{a}} \\
60^{\mathrm{a}}\end{array}$ & IRa & $\mathrm{m}^{3} / \mathrm{h}$ & $\begin{array}{l}\text { Adults } \\
\text { children }\end{array}$ & $\begin{array}{c}7.63 \\
20\end{array}$ \\
\hline EF & days/year & $\begin{array}{l}\text { Adults } \\
\text { Children }\end{array}$ & $\begin{array}{l}350^{\mathrm{b}} \\
350^{\mathrm{b}}\end{array}$ & ABS & unitless & $\begin{array}{l}\text { Arsenic } \\
\text { others }\end{array}$ & $\begin{array}{l}0.03^{b, c} \\
0.001^{d, c}\end{array}$ \\
\hline ED & years & $\begin{array}{l}\text { Adults } \\
\text { Children }\end{array}$ & $\begin{array}{c}30^{\mathrm{b}} \\
6^{\mathrm{b}}\end{array}$ & $\mathrm{AF}$ & unitless & $\begin{array}{l}\text { Adults } \\
\text { children }\end{array}$ & $\begin{array}{l}0.07^{\mathrm{b}} \\
0.2^{\mathrm{b}}\end{array}$ \\
\hline AT & days & $\begin{array}{l}\text { Non-carcinogenic effects } \\
\text { Carcinogenic effects }\end{array}$ & $\begin{array}{l}\mathrm{ED} \times 365^{\mathrm{b}} \\
\mathrm{ED} \times 70^{\mathrm{b}}\end{array}$ & ET & h/day & $\begin{array}{l}\text { Adults } \\
\text { children }\end{array}$ & $\begin{array}{c}14 \\
8\end{array}$ \\
\hline BW & $\mathrm{kg}$ & $\begin{array}{l}\text { Adults } \\
\text { Children }\end{array}$ & $\begin{array}{l}70^{\mathrm{b}} \\
15^{\mathrm{b}}\end{array}$ & SA & $\mathrm{cm}^{2}$ & $\begin{array}{l}\text { Adults } \\
\text { children }\end{array}$ & $\begin{array}{l}5700^{b} \\
2800^{b}\end{array}$ \\
\hline
\end{tabular}
ABS represents the dermal absorption fraction; SA represents the skin surface area available for contact $\left(\mathrm{cm}^{2}\right)$; and EV represents the event frequency (events/day). These parameters are shown in Table 2.

Table 2. The value of parameters for exposure dose. 
Table 2. Cont.

\begin{tabular}{cccccccc}
\hline $\mathrm{CF}$ & $\mathrm{kg} / \mathrm{mg}$ & - & $10^{-6}$ & $\mathrm{PEF}$ & $\mathrm{kg} / \mathrm{m}^{3}$ & & $1.36 \times 10^{9}$ \\
$\mathrm{FI}$ & unitless & - & $1^{\mathrm{b}}$ & $\mathrm{EV}$ & $\begin{array}{c}1.36 \\
\text { events/day }\end{array}$ & - & $1^{\mathrm{b}}$ \\
\hline
\end{tabular}

\subsubsection{Non-Carcinogenic Health Risk}

Hazard quotient (HQ) and hazard index (HI) can be used to assess the non-carcinogenic health risk for both adults and children. HQ is the individual value for each element, and $\mathrm{HI}$ is the sum of $\mathrm{HQ}$. These equations are as follows:

$$
\begin{aligned}
& \mathrm{HQ}=\frac{\mathrm{ADD}}{\mathrm{RfD}} \\
& \mathrm{HI}=\sum \mathrm{HQ}
\end{aligned}
$$

where ADD represents the ingestion, inhalation and dermal daily dose, which are mentioned above; $\mathrm{RfD}$ is a specific reference dose, which can be obtained from the Integrated Information Risk System (IRIS) [37]. If $\mathrm{HQ}>1$, it implies an adverse effect on human health. Otherwise, if $\mathrm{HQ}<1$, the results are the opposite. The safe limit of $\mathrm{HI}$ is also 1 . If $\mathrm{HI}<1$, there is no significant risk of non-carcinogenic effects; otherwise it has the opposite effect.

\subsubsection{Risk Calculation}

The reference values of carcinogenic risk through dermal exposure and ingestion were not provided by the USEPA, so it cannot calculate the excess cancer risks (ECR) on the two exposure pathways except for inhalation. Furthermore, the inhalation pathway can only consider the carcinogenic risk of metals. Aside from this point, not all metals can cause cancer. In our study, 16 elements were tested, but only $\mathrm{Cr}, \mathrm{Ni}, \mathrm{As}, \mathrm{Cd}, \mathrm{Pb}$ were related to cancer (IRIS) [37]. Hence, only five elements were considered when we calculated the cancer risk. The ECR for an exposed receptor can be assessed with the following equation [18]:

$$
\mathrm{ECR}_{\text {inh }}=\mathrm{SF} \times \mathrm{ADD}_{\text {inh }}=\frac{\mathrm{IUR} \times \mathrm{BW}}{\mathrm{IR}_{\mathrm{a}}} \times \frac{\mathrm{C} \times \mathrm{IR}_{\mathrm{a}} \times \mathrm{ET} \times \mathrm{EF} \times \mathrm{ED}}{\mathrm{PEF} \times \mathrm{BW} \times \mathrm{AT}}=\frac{\mathrm{C} \times \mathrm{ET} \times \mathrm{EF} \times \mathrm{ED} \times \mathrm{IUR}}{\mathrm{PEF} \times \mathrm{AT}}
$$

SF represents the cancer slope factor; and IUR represents the inhalation unit risk. Usually, the default approach recommended for determining predictive cancer risk is a linear extrapolation from the exposures observed in the animal or human occupational study. The slope of this line is commonly called the slope factor, and the units are defined as IUR [30]. The IUR values of $\mathrm{Pb}, \mathrm{Ni}, \mathrm{As}$, $\mathrm{Cd}$ and $\mathrm{Cr}$ are $1.2 \times 10^{-5}, 2.4 \times 10^{-4}, 4.3 \times 10^{-3}, 1.8 \times 10^{-3}$, and $0.012\left(\mu \mathrm{g} / \mathrm{m}^{3}\right)^{-1}$, respectively [34]; ET represents the exposure time, which in this study was $8 \mathrm{~h} /$ day. The other parameters were the same as those mentioned earlier. The safe limit of ECR is the range $10^{-6}-10^{-4}$.

\section{Results and Discussion}

\subsection{Road Dust Metals Concentration}

Metal concentrations of the road dust and the summary statistics of the study area are listed in Table 3. The metals can be classified into two groups: major and trace elements. Metal concentrations of the trace elements followed the sequence: $\mathrm{Hg}>\mathrm{Mn}>\mathrm{Zn}>\mathrm{Pb}>\mathrm{Cr}>\mathrm{Cu}>\mathrm{V}>\mathrm{As}>\mathrm{Ni}>\mathrm{Co}>\mathrm{Cd}$. Comparing the CNEMC values, all concentrations of the major elements were relatively lower; on the other hand, the concentrations of the trace elements were higher, except for Mn and V. Furthermore, the mean concentrations of $\mathrm{Cd}, \mathrm{Pb}, \mathrm{As}$, and $\mathrm{Hg}$ were 214.3, 3.29, 5.97, and 14,000 times that of the CNEMC values, respectively; this was significantly higher than the other elements, which may be derived from anthropogenic sources. 
Table 3. Metal concentrations and summary statistics (mg/kg).

\begin{tabular}{|c|c|c|c|c|c|c|c|c|}
\hline Elements & $n^{\mathrm{a}}$ & Range (mg/kg) & Mean $\pm \mathrm{SD}(\mathrm{mg} / \mathrm{kg})$ & Median (mg/kg) & $\mathrm{CV}$ & Skewness & Kurtosis & CNEMC Value $^{\mathrm{b}}(\mathrm{mg} / \mathrm{kg}$ \\
\hline \multicolumn{9}{|c|}{ Major elements } \\
\hline $\mathrm{Fe}$ & 100 & $5.47 \times 10^{3}-2.46 \times 10^{4}$ & $1.33 \times 10^{4} \pm 2.87 \times 10^{3}$ & $1.28 \times 10^{5}$ & 0.22 & 0.98 & 2.29 & $2.74 \times 10^{4}$ \\
\hline $\mathrm{Mg}$ & 100 & $2.30 \times 10^{3}-7.80 \times 10^{3}$ & $3.54 \times 10^{3} \pm 7.67 \times 10^{2}$ & $3.43 \times 10^{3}$ & 0.22 & 2.26 & 9.44 & $6.8 \times 10^{3}$ \\
\hline $\mathrm{Al}$ & 100 & $3.12 \times 10^{3}-2.19 \times 10^{4}$ & $6.08 \times 10^{3} \pm 2.21 \times 10^{3}$ & $6.08 \times 10^{3}$ & 0.36 & 4.21 & 26.63 & $5.95 \times 10^{4}$ \\
\hline $\mathrm{Ba}$ & 100 & $68.77-780.97$ & $193.97 \pm 126.71$ & 150.97 & 0.65 & 2.34 & 5.95 & 529.00 \\
\hline $\mathrm{Sr}$ & 100 & $25.22-140.86$ & $75.74 \pm 21.28$ & 77.69 & 0.28 & 0.03 & 0.22 & 187.00 \\
\hline \multicolumn{9}{|c|}{ Trace elements } \\
\hline $\mathrm{Mn}$ & 100 & $249.15-594.94$ & $375.64 \pm 64.63$ & 367.49 & 0.17 & 1.01 & 1.75 & 636.00 \\
\hline $\mathrm{Cr}$ & 100 & $30.36-208.69$ & $65.53 \pm 23.21$ & 62.52 & 0.17 & 1.01 & 1.75 & 46.70 \\
\hline $\mathrm{Ni}$ & 100 & $14.84-86.37$ & $35.47 \pm 9.03$ & 35.47 & 0.25 & 2.02 & 11.00 & 21.40 \\
\hline $\mathrm{Cd}$ & 100 & $1.98-36.73$ & $21.43 \pm 12.29$ & 28.83 & 0.57 & -0.92 & -1.14 & 0.10 \\
\hline Co & 100 & $9.56-41.27$ & $29.96 \pm 11.67$ & 36.70 & 0.39 & -0.92 & -1.11 & 11.90 \\
\hline $\mathrm{Cu}$ & 100 & $17.37-135.59$ & $53.73 \pm 21.66$ & 50.36 & 0.40 & 1.21 & 2.29 & 17.10 \\
\hline $\mathrm{Zn}$ & 100 & $34.56-419.86$ & $169.79 \pm 70.56$ & 162.22 & 0.42 & 0.82 & 1.20 & 80.40 \\
\hline $\mathrm{Pb}$ & 100 & $23.94-385.35$ & $94.99 \pm 67.99$ & 73.31 & 0.72 & 2.26 & 5.86 & 28.80 \\
\hline As & 95 & $0.56-144.27$ & $47.72 \pm 37.09$ & 36.32 & 0.78 & 0.69 & -0.68 & 8.00 \\
\hline $\mathrm{Hg}$ & 73 & $0.53-1127.24$ & $560.90 \pm 294.68$ & 543.43 & 0.53 & 0.04 & -0.83 & 0.04 \\
\hline V & 100 & $17.55-79.85$ & $54.41 \pm 15.77$ & 60.05 & 0.29 & -0.72 & -0.89 & 68.00 \\
\hline
\end{tabular}

${ }^{\text {a }}$ The $n$ means effective data number; ${ }^{\text {b }}$ China National Environmental Monitoring Center (CNEMC) [38].

Table 4. Elements concentrations $\left(\mathrm{mg} \mathrm{kg}^{-1}\right)$ in road/street dust of different cities in China and other countries.

\begin{tabular}{|c|c|c|c|c|c|c|c|c|c|c|c|c|c|c|c|c|c|c|}
\hline City & Year & Mn & $\mathrm{Fe}$ & Mg & Al & Ва & Sr & $\mathrm{Cr}$ & $\mathrm{Ni}$ & Cd & Co & $\mathrm{Cu}$ & $\mathrm{Zn}$ & $\mathrm{Pb}$ & As & $\mathrm{Hg}$ & V & References \\
\hline Baoji, China & 2010 & 804.20 & - & - & - & - & - & 123.00 & 42.00 & - & 16.00 & 113.00 & 612.00 & 383.00 & 18.00 & - & 31.40 & [29] \\
\hline Tehran, Iran & 2012 & - & - & - & - & - & - & 33.50 & 34.80 & 10.70 & & 225.30 & 873.20 & 257.40 & & - & - & [7] \\
\hline Nanjing, China & 2013 & 646.00 & $3.42 \times 10^{5}$ & - & - & - & - & 126.00 & - & - & 11.00 & 123.00 & 394.00 & 103.00 & 13.00 & - & - & [39] \\
\hline Isfahan, Iran & 2015 & - & - & - & - & - & - & 82.13 & 70.04 & 2.14 & 13.93 & 182.26 & 707.19 & 393.33 & 22.15 & - & - & [10] \\
\hline Villavicencio, Colombia & & & & & - & - & - & 25.63 & 22.27 & 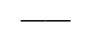 & - & 213.40 & 289.73 & 467.63 & - & - & - & [40] \\
\hline Thessaloniki, Greece & 2016 & 529.10 & $2.51 \times 10^{5}$ & $9.50 \times 10^{3}$ & $2.92 \times 10^{4}$ & & & 187.30 & 95.71 & 0.59 & 9.55 & 526.20 & 671.00 & 191.00 & 13.20 & - & 53.70 & [14] \\
\hline Changchun, China & & 375.64 & $1.33 \times 10^{5}$ & $3.54 \times 10^{3}$ & $6.08 \times 10^{3}$ & 193.97 & 75.74 & 65.53 & 35.47 & 21.43 & 29.96 & 53.73 & 169.79 & 94.99 & 47.72 & 54.41 & 54.41 & This study \\
\hline Hefei, China & 2017 & 240.50 & $8.69 \times 10^{3}$ & $5.35 \times 10^{3}$ & $8.39 \times 10^{3}$ & 12.20 & - & 139.30 & 28.60 & - & 7.20 & 41.60 & 130.10 & 0.90 & 2.00 & - & 31.40 & [41] \\
\hline & & 510.50 & - & - & - & - & - & 145.00 & 30.80 & - & 30.90 & & 268.60 & 124.50 & & - & 69.60 & [42] \\
\hline Beijing, China & 2018 & 553.73 & 280.65 & - & - & - & - & 92.10 & 32.47 & 0.59 & & 83.12 & 280.65 & 60.88 & 4.88 & 0.16 & - & [43] \\
\hline
\end{tabular}


The statistical characteristics included standard deviation (SD), the coefficient of variation (CV), skewness and kurtosis, which were calculated as presented in Table 3. CV is used to represent the discrete degree of data. CV $\leq 20 \%$, low variability; $21 \%<\mathrm{CV} \leq 50 \%$, moderate variability; $50 \%<\mathrm{CV} \leq$ $100 \%$, high variability; CV >100\%, very high variability. In this study, concentrations of $\mathrm{Ba}, \mathrm{Cd}, \mathrm{Pb}, \mathrm{As}$, and $\mathrm{Hg}$ indicated high variability. The metals of $\mathrm{Cd}, \mathrm{Pb}, \mathrm{As}$, and $\mathrm{Hg}$ varied widely between the different sampling sites, which further indicated anthropogenic sources. All these metals are related to traffic, state of the roads, tires, and brake wear, lubricants and paints and fuels $[13,40,44]$. The concentrations of $\mathrm{Mn}$ and $\mathrm{Cr}$ showed small differences while the others showed moderate variability.

The concentrations of the elements in road dust in this study were compared to different sites domestic and overseas, which are also presented in Table 4. Only the accumulation of $\mathrm{Cr}$ was lower than in other cities. The mean levels of $\mathrm{Cd}$, As, and $\mathrm{Hg}$ were significantly higher than those in other sites.

\subsection{Geo-Accumulation Index}

The $\mathrm{I}_{\text {geo }}$ values of elements were calculated in the road dust of Changchun, which are listed in Figure 2. The mean $\mathrm{I}_{\text {geo }}$ values of the elements followed the decreasing trend: $\mathrm{Hg}(12.87)>\mathrm{Cd}(6.56)$ $>\mathrm{Cu}(0.96)>\mathrm{Pb}(0.88)>\mathrm{Co}(0.58)>\mathrm{Zn}(0.36)>\mathrm{Ni}(0.10)>\mathrm{Cr}(-0.16)>\mathrm{V}(-0.98)>\mathrm{Mn}(-1.37)>$ $\mathrm{Mg}(-1.55)>\mathrm{Fe}(-1.66)>\mathrm{Sr}(-1.95)>\mathrm{Ba}(-2.24)>\mathrm{Al}(-3.94)>\mathrm{As}(-10.37)$. The $\mathrm{I}_{\text {geo }}$ value of $\mathrm{Hg}$ was the highest, followed by $\mathrm{Cd}$ and $\mathrm{Cu}$. According to the classifications and other studies $[15,22,40]$, the average $\mathrm{I}_{\text {geo }}$ values indicated no contamination of the road dust by $\mathrm{Mn}, \mathrm{Cr}, \mathrm{Fe}, \mathrm{Mg}, \mathrm{Al}, \mathrm{Ba}, \mathrm{Sr}$, As and V; no contamination to moderately contaminated by $\mathrm{Ni}, \mathrm{Co}, \mathrm{Cu}, \mathrm{Zn}$, and $\mathrm{Pb}$; and extremely contaminated by $\mathrm{Hg}$ and $\mathrm{Cd}$.

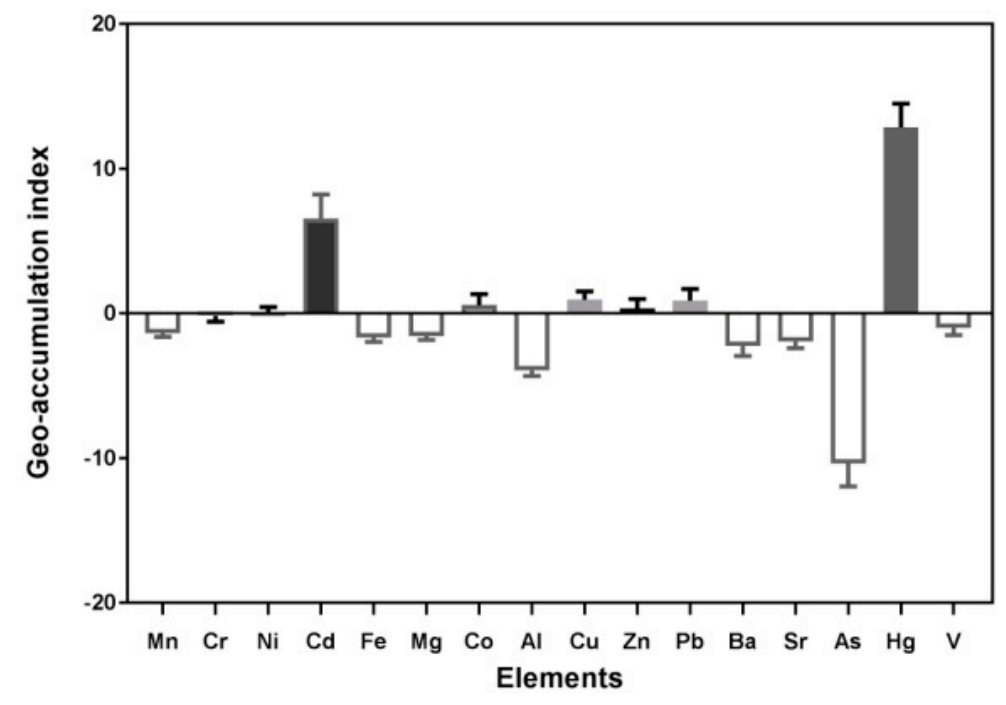

Figure 2. Boxplots of the geo-accumulation index $\left(\mathrm{I}_{\mathrm{geo}}\right)$ for 16 elements in road dust.

In addition, there was a wide range of values of elements presented in Figure 2, that indicated that the element contamination values varied by the diverse population, urban construction, traffic source, demolition activities, residential burning, industrial distribution, and other factors [43,45].

\subsection{Enrichment Factor}

The element of $\mathrm{Al}$ was selected as a reference value, and the results are presented in Figure 3. The EF of Cd, As, Hg was 18.31-384.22, 0.82-211.44, and 58.32-285.39, with the average of 225.55, 68.38, and 150.46, which indicated extremely high enrichment. The EF of $\mathrm{Co}, \mathrm{Cu}, \mathrm{Zn}$, and $\mathrm{Pb}$ were 8.26-56.25, 9.15-94.22, 3.28-63.01 and 5.40-196.57, with an average of 26.20, 32.86, 22.01, and 34.53, respectively, which revealed a very high enrichment. The elements of $\mathrm{Mn}, \mathrm{Cr}, \mathrm{Ni}, \mathrm{Fe}$, and $\mathrm{Mg}$ showed significant 
enrichment, with the mean value ranging from 5-20. Ba and Sr were considered to originate primarily from natural sources, while the mean EF values were 3.68 and 4.2, respectively. The mean EF values exhibited the increasing trend: $\mathrm{Ba}<\mathrm{Sr}<\mathrm{Fe}<\mathrm{Mg}<\mathrm{Mn}<\mathrm{V}<\mathrm{Cr}<\mathrm{Ni}<\mathrm{Zn}<\mathrm{Co}<\mathrm{Cu}<\mathrm{Pb}<\mathrm{As}<$ $\mathrm{Hg}<\mathrm{Cd}$. The trends revealed that the carcinogenic elements had a higher enrichment than others, which showed significant anthropogenic sources.

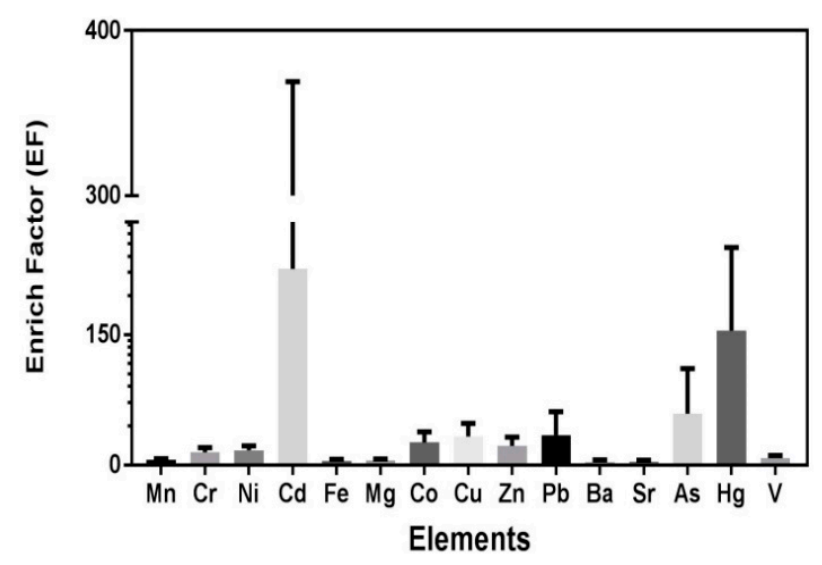

Figure 3. Boxplots of the enrichment factors (EF) for 16 elements in road dust.

\subsection{Exposure Dose}

Table 5 shows the average daily dose (ADD) for the non-carcinogenic elements of road dust through three different exposure pathways, which revealed the same trend in adults and children, $\mathrm{ADD}_{\text {ing }}>\mathrm{ADD}_{\text {derm }}>\mathrm{ADD}_{\text {inh }}$. This situation was similar to what is seen in previous studies $[22,23,44,46]$. The ingestion exposure pathway is 2 to 4 orders higher than the other two types. Among the ADD of road dust, the elements Fe and Al had the maximum dose, while Cd had the minimum dose. According to the calculations, the total ADD for children was 5.2 times higher than adults, which indicates that children are exposed to more elements than adults. However, as there are various components in road dust, such as polycyclic aromatic hydrocarbons (PAHs), polybrominated diphenyl ethers (PBDEs), persistent organic pollutants (POPs), a higher dose does not necessarily indicate a higher risk while ignoring the assessment of others. Only five elements $(\mathrm{Cr}, \mathrm{Ni}, \mathrm{Cd}, \mathrm{Pb}$ and As) had different carcinogenic effects on humans through IRIS, so the ADD for the carcinogenicity of the above five elements could be calculated, which are shown in Figure 4. It had the same trend in children and adults when compared to the non-carcinogenic assessment.

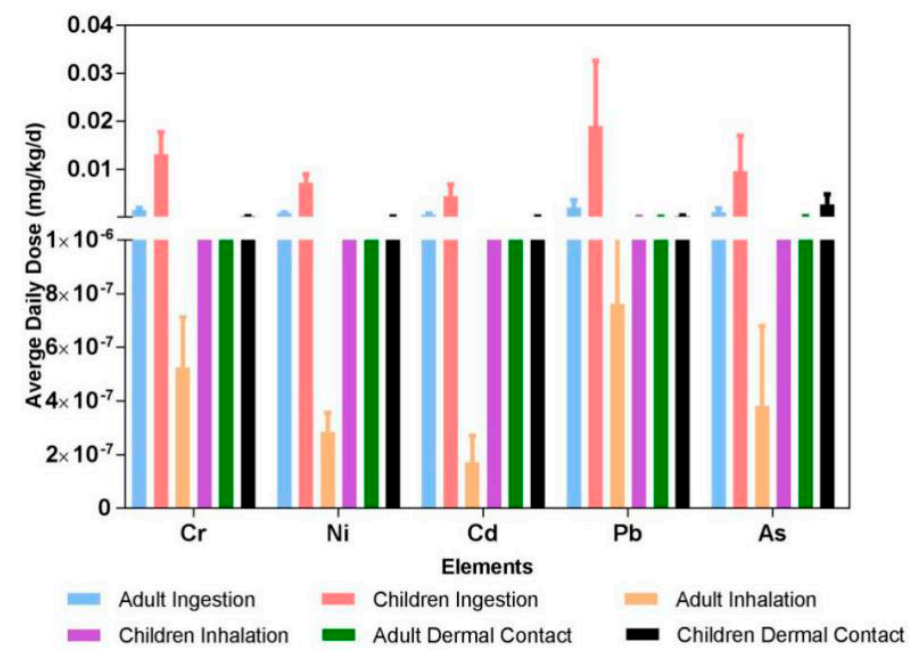

Figure 4. Average daily exposure dose for carcinogenic elements. 
Table 5. Average daily exposure dose for non-carcinogenic elements through ingestion, inhalation and dermal contact.

\begin{tabular}{|c|c|c|c|c|c|c|c|c|c|c|c|c|c|c|c|c|c|}
\hline Type & Data & Mn & $\mathrm{Cr}$ & $\mathrm{Ni}$ & $\mathrm{Cd}$ & $\mathrm{Fe}$ & $\mathrm{Mg}$ & Co & $\mathrm{Al}$ & $\mathrm{Cu}$ & $\mathrm{Zn}$ & $\mathrm{Pb}$ & Ва & $\mathrm{Sr}$ & As & $\mathrm{Hg}$ & $\mathrm{v}$ \\
\hline \multicolumn{18}{|c|}{ Ingestion } \\
\hline \multirow[t]{3}{*}{ Adults } & Min & $1.02 \times 10^{-3}$ & $1.25 \times 10^{-4}$ & $6.10 \times 10^{-5}$ & $8.12 \times 10^{-6}$ & $2.25 \times 10^{-2}$ & $9.44 \times 10^{-3}$ & $3.93 \times 10^{-5}$ & $1.28 \times 10^{-2}$ & $7.14 \times 10^{-5}$ & $1.42 \times 10^{-4}$ & $9.84 \times 10^{-5}$ & $2.83 \times 10^{-4}$ & $1.04 \times 10^{-4}$ & $1.77 \times 10^{-5}$ & $4.64 \times 10^{-3}$ & $7.21 \times 10^{-5}$ \\
\hline & $\operatorname{Max}$ & $2.44 \times 10^{-3}$ & $8.58 \times 10^{-4}$ & $3.55 \times 10^{-4}$ & $1.51 \times 10^{-4}$ & 0.10 & $3.21 \times 10^{-2}$ & $1.70 \times 10^{-4}$ & $9.01 \times 10^{-2}$ & $5.57 \times 10^{-4}$ & $1.73 \times 10^{-3}$ & $1.58 \times 10^{-3}$ & $3.21 \times 10^{-3}$ & $5.79 \times 10^{-4}$ & $5.93 \times 10^{-4}$ & $4.63 \times 10^{-3}$ & $3.28 \times 10^{-4}$ \\
\hline & Mean & $54 \times 10^{-3}$ & $2.69 \times 10^{-4}$ & $46 \times 10^{-4}$ & $8.81 \times 10^{-5}$ & $5.46 \times 10^{-2}$ & $1.46 \times 10^{-2}$ & $1.23 \times 10^{-4}$ & $2.50 \times 10^{-2}$ & $2.21 \times 10^{-4}$ & $6.98 \times 10^{-4}$ & $3.90 \times 10^{-4}$ & $7.97 \times 10^{-4}$ & $3.11 \times 10^{-4}$ & $1.86 \times 10^{-4}$ & $1.07 \times 10^{-3}$ & $2.24 \times 10^{-4}$ \\
\hline \multirow[t]{3}{*}{ Children } & Min & $34 \times 10^{-3}$ & $6.51 \times 10^{-4}$ & $3.18 \times 10^{-4}$ & $4.24 \times 10^{-5}$ & 0.12 & $4.92 \times 10^{-2}$ & $2.05 \times 10^{-4}$ & $6.68 \times 10^{-2}$ & $3.72 \times 10^{-4}$ & $7.41 \times 10^{-4}$ & $5.13 \times 10^{-4}$ & $1.47 \times 10^{-3}$ & $5.41 \times 10^{-4}$ & $1.23 \times 10^{-5}$ & $1.42 \times 10^{-3}$ & $3.76 \times 10^{-4}$ \\
\hline & Max & $1.27 \times 10^{-2}$ & $4.47 \times 10^{-3}$ & $1.85 \times 10^{-3}$ & $7.87 \times 10^{-4}$ & 0.53 & 0.17 & $8.84 \times 10^{-4}$ & 0.47 & $2.91 \times 10^{-3}$ & $9.00 \times 10^{-3}$ & $8.26 \times 10^{-3}$ & $1.67 \times 10^{-2}$ & $3.02 \times 10^{-3}$ & $3.09 \times 10^{-3}$ & $2.42 \times 10^{-2}$ & $1.71 \times 10^{-3}$ \\
\hline & Mean & $8.05 \times 10^{-3}$ & $1.40 \times 10^{-3}$ & $7.60 \times 10^{-4}$ & $4.59 \times 10^{-4}$ & 0.29 & $7.59 \times 10^{-2}$ & $6.42 \times 10^{-4}$ & 0.13 & $1.15 \times 10^{-3}$ & $3.64 \times 10^{-3}$ & $2.04 \times 10^{-3}$ & $4.16 \times 10^{-3}$ & $1.62 \times 10^{-3}$ & $9.69 \times 10^{-4}$ & $5.57 \times 10^{-3}$ & $1.17 \times 10^{-3}$ \\
\hline \multicolumn{18}{|c|}{ Inhalation } \\
\hline \multirow[t]{3}{*}{ Adults } & Min & $3.83 \times 10^{-7}$ & $4.67 \times 10^{-8}$ & $2.28 \times 10^{-8}$ & $3.04 \times 10^{-9}$ & $8.41 \times 10^{-6}$ & $3.53 \times 10^{-6}$ & $1.47 \times 10^{-8}$ & $4.79 \times 10^{-6}$ & $2.67 \times 10^{-8}$ & $5.31 \times 10^{-8}$ & $3.68 \times 10^{-8}$ & $1.06 \times 10^{-7}$ & $3.88 \times 10^{-8}$ & $1.62 \times 10^{-9}$ & $7.34 \times 10^{-8}$ & $2.70 \times 10^{-8}$ \\
\hline & Max & $9.14 \times 10^{-7}$ & $3.21 \times 10^{-7}$ & $33 \times 10^{-7}$ & $5.65 \times 10^{-8}$ & $3.79 \times 10^{-5}$ & $1.20 \times 10^{-5}$ & $6.34 \times 10^{-8}$ & $3.37 \times 10^{-5}$ & $2.08 \times 10^{-7}$ & $6.45 \times 10^{-7}$ & $5.92 \times 10^{-7}$ & $\times 10^{-6}$ & $2.17 \times 10^{-7}$ & $2.22 \times 10^{-7}$ & $1.73 \times 10^{-6}$ & $1.23 \times 10^{-7}$ \\
\hline & Mean & $5.77 \times 10^{-7}$ & $1.01 \times$ & $45 \times 10^{-8}$ & $3.29 \times 10^{-8}$ & $2.04 \times 10^{-5}$ & $5.44 \times 10^{-6}$ & $4.60 \times 10^{-8}$ & $9.35 \times 10^{-6}$ & $8.26 \times 10^{-8}$ & $2.61 \times 10^{-7}$ & $1.46 \times 10^{-7}$ & $2.98 \times$ & $1.16 \times 10^{-7}$ & $6.95 \times 10^{-8}$ & $3.99 \times 10^{-7}$ & $8.36 \times 10^{-8}$ \\
\hline \multirow[t]{3}{*}{ Children } & Min & $4.68 \times 10^{-6}$ & $5.71 \times$ & $.79 \times 10^{-7}$ & $3.72 \times 10^{-8}$ & $1.03 \times 10^{-4}$ & $4.32 \times 10^{-5}$ & $1.80 \times 10^{-7}$ & $5.87 \times 10^{-5}$ & $3.27 \times 10^{-7}$ & $6.50 \times 10^{-7}$ & $4.50 \times 10^{-7}$ & $1.29 \times$ & $4.74 \times 10^{-7}$ & $8.10 \times 10^{-8}$ & $2.12 \times 10^{-6}$ & $3.30 \times 10^{-7}$ \\
\hline & $\operatorname{Max}$ & $2 \times 10^{-5}$ & & & & & $1.47 \times 10^{-4}$ & $7.76 \times 10^{-7}$ & $12 \times 10^{-4}$ & $55 \times 10^{-6}$ & $7.89 \times$ & $7.25 \times 10^{-6}$ & $1.47 \times$ & $2.65 \times 10^{-6}$ & $2.71 \times 10^{-6}$ & $2.12 \times 10^{-5}$ & $1.50 \times 10^{-6}$ \\
\hline & Mean & $7.06 \times 10^{-6}$ & $1.23 \times 10^{-6}$ & $6.67 \times 10^{-7}$ & $4.03 \times 10^{-7}$ & $2.50 \times 10^{-4}$ & $6.66 \times 10^{-5}$ & $5.63 \times 10^{-7}$ & $1.14 \times 10^{-4}$ & $1.01 \times 10^{-6}$ & $3.19 \times 10^{-6}$ & $1.79 \times 10^{-6}$ & $3.65 \times 10^{-6}$ & $1.42 \times 10^{-6}$ & $8.50 \times 10^{-7}$ & $4.88 \times 10^{-6}$ & $1.02 \times 10^{-6}$ \\
\hline \multicolumn{18}{|c|}{ Dermal contact } \\
\hline \multirow[t]{3}{*}{ Adults } & Min & $1.36 \times 10^{-5}$ & $1.66 \times 10^{-6}$ & $8.11 \times 10^{-7}$ & $1.08 \times 10^{-7}$ & $2.99 \times 10^{-4}$ & $1.26 \times 10^{-4}$ & $5.23 \times 10^{-7}$ & $1.70 \times 10^{-4}$ & $9.49 \times 10^{-7}$ & $1.89 \times 10^{-6}$ & $1.31 \times 10^{-6}$ & & & $1.06 \times 10^{-6}$ & $6.17 \times 10^{-6}$ & $9.59 \times 10^{-7}$ \\
\hline & Max & & $1.14 \times 10^{-5}$ & & & & & & & & & & & & & & \\
\hline & Mean & $2.05 \times 10^{-5}$ & $3.58 \times 10^{-6}$ & & $1.17 \times 10^{-6}$ & $7.26 \times 10$ & $1.94 \times 10$ & $1.64 \times 1$ & & & $9.28 \times 1$ & & & & $7.41 \times 1$ & & $2.97 \times 10^{-6}$ \\
\hline \multirow{3}{*}{ Children } & Min & $8.92 \times 10^{-5}$ & $1.09 \times 10^{-5}$ & $5.31 \times 10^{-6}$ & $7.08 \times 10^{-7}$ & $1.96 \times 10^{-3}$ & $8.23 \times 10^{-4}$ & $3.42 \times 10^{-6}$ & $1.12 \times 10^{-3}$ & $6.22 \times 10^{-6}$ & $1.24 \times 10^{-5}$ & $8.57 \times 10^{-6}$ & $2.46 \times 10^{-5}$ & $9.03 \times 10^{-6}$ & $4.63 \times 10^{-5}$ & $4.04 \times 10^{-4}$ & $6.28 \times 10^{-6}$ \\
\hline & Max & $2.13 \times 10^{-4}$ & $7.47 \times 10^{-5}$ & $3.09 \times 10^{-5}$ & $1.31 \times 10^{-5}$ & $8.82 \times 10^{-3}$ & $2.79 \times 10^{-3}$ & $1.48 \times 10^{-5}$ & $7.85 \times 10^{-3}$ & $4.85 \times 10^{-5}$ & $1.50 \times 10^{-4}$ & $1.38 \times 10^{-4}$ & $2.80 \times 10^{-4}$ & $5.04 \times 10^{-5}$ & $1.55 \times 10^{-3}$ & $4.04 \times 10^{-4}$ & $2.86 \times 10^{-5}$ \\
\hline & Mean & $1.34 \times 10^{-4}$ & $2.35 \times 10^{-5}$ & $1.27 \times 10^{-5}$ & $7.67 \times 10^{-6}$ & $4.76 \times 10^{-3}$ & $1.27 \times 10^{-3}$ & $1.07 \times 10^{-5}$ & $2.18 \times 10^{-3}$ & $1.92 \times 10^{-5}$ & $6.08 \times 10^{-5}$ & $3.40 \times 10^{-5}$ & $6.94 \times 10^{-5}$ & $2.71 \times 10^{-5}$ & $4.85 \times 10^{-4}$ & $9.30 \times 10^{-5}$ & $1.95 \times 10^{-5}$ \\
\hline \multicolumn{18}{|c|}{ Total exposure } \\
\hline & & $1.56 \times 10^{-3}$ & $2.73 \times 10^{-4}$ & $1.48 \times 10^{-4}$ & $8.93 \times 10^{-5}$ & $5.53 \times 10^{-2}$ & $1.48 \times 10^{-2}$ & $1.25 \times 10^{-4}$ & $2.53 \times 10^{-2}$ & $2.24 \times 10^{-4}$ & $7.08 \times 10^{-4}$ & $3.95 \times 10^{-4}$ & $8.08 \times 10^{-4}$ & $3.15 \times 10^{-4}$ & $2.60 \times 10^{-4}$ & $1.08 \times 10^{-3}$ & $2.27 \times 10^{-4}$ \\
\hline Children & & $8.19 \times 10^{-3}$ & $1.42 \times 10^{-3}$ & $7.73 \times 10^{-4}$ & $4.67 \times 10^{-4}$ & 0.29 & $7.72 \times 10^{-2}$ & $6.53 \times 10^{-4}$ & 0.13 & $1.17 \times 10^{-3}$ & $3.70 \times 10^{-3}$ & $2.08 \times 10^{-3}$ & $4.23 \times 10^{-3}$ & $1.65 \times 10^{-3}$ & $1.45 \times 10^{-3}$ & $5.67 \times 10^{-3}$ & $1.19 \times 10^{-3}$ \\
\hline
\end{tabular}

Table 6. Hazard Quotient and Hazard Index for adults and children.

\begin{tabular}{|c|c|c|c|c|c|c|c|c|c|c|c|c|c|c|c|c|}
\hline Type & Data & Mn & $\mathrm{Cr}$ & $\mathrm{Ni}$ & $\mathrm{Cd}$ & $\mathrm{Fe}$ & $\mathrm{Mg}$ & Co & $\mathrm{Cu}$ & $\mathrm{Zn}$ & $\mathrm{Pb}$ & Ва & $\mathrm{Sr}$ & As & $\mathrm{Hg}$ & $\mathrm{v}$ \\
\hline \multirow{4}{*}{ Adults } & HQing & $1.10 \times 10^{-2}$ & $8.98 \times 10^{-2}$ & $7.29 \times 10^{-3}$ & $8.81 \times 10^{-2}$ & - & 0.10 & $6.16 \times 10^{-3}$ & $5.97 \times 10^{-3}$ & $2.33 \times 10^{-3}$ & 0.11 & $3.99 \times 10^{-3}$ & $5.19 \times 10^{-4}$ & 0.65 & 7.63 & $3.19 \times 10^{-2}$ \\
\hline & HQinh & $1.15 \times 10^{-2}$ & $3.52 \times 10^{-3}$ & $2.65 \times 10^{-6}$ & $3.29 \times 10^{-5}$ & - & 0.10 & $8.06 \times 10^{-3}$ & $2.05 \times 10^{-6}$ & $8.70 \times 10^{-7}$ & $4.15 \times 10^{-5}$ & $2.08 \times 10^{-3}$ & - & & $9.99 \times 10^{-3}$ & \\
\hline & HQderm & $1.12 \times 10^{-2}$ & $1.43 \times 10^{-2}$ & $1.94 \times 10^{-3}$ & $2.34 \times 10^{-2}$ & - & - & $1.02 \times 10^{-4}$ & $1.55 \times 10^{-3}$ & $1.55 \times 10^{-4}$ & $9.89 \times 10^{-3}$ & $2.16 \times 10^{-3}$ & & 0.26 & 14.50 & $3.30 \times 10^{-4}$ \\
\hline & HI & $3.37 \times 10^{-2}$ & 0.11 & $9.23 \times 10^{-3}$ & 0.11 & - & 0.211 & $1.43 \times 10^{-2}$ & $7.51 \times 10^{-3}$ & $2.48 \times 10^{-3}$ & 0.12 & $8.23 \times 10^{-3}$ & $5.19 \times 10^{-4}$ & 0.92 & 22.10 & $3.23 \times 10^{-2}$ \\
\hline \multirow{4}{*}{ Children } & HQing & $1.80 \times 10^{-2}$ & 0.45 & $4.11 \times 10^{-2}$ & 0.87 & - & $8.21 \times 10^{-3}$ & 11.70 & 0.18 & $1.21 \times 10^{-2}$ & 2.13 & $1.45 \times 10^{-2}$ & $2.89 \times 10^{-3}$ & 219.00 & 7.93 & - \\
\hline & HQinh & 0.14 & $4.31 \times 10^{-2}$ & $3.24 \times 10^{-5}$ & $4.03 \times 10^{-4}$ & - & 1.33 & $9.86 \times 10^{-2}$ & $2.51 \times 10^{-5}$ & $1.06 \times 10^{-5}$ & $5.07 \times 10^{-4}$ & $2.55 \times 10^{-2}$ & - & & 0.12 & \\
\hline & HQderm & $7.31 \times 10^{-2}$ & $9.38 \times 10^{-2}$ & $1.27 \times 10^{-2}$ & 0.15 & - & - & $6.70 \times 10^{-4}$ & $1.01 \times 10^{-2}$ & $1.01 \times 10^{-3}$ & $6.48 \times 10^{-2}$ & $1.42 \times 10^{-2}$ & - & 1.71 & 94.90 & $2.16 \times 10^{-3}$ \\
\hline & HI & 0.23 & 0.59 & $5.38 \times 10^{-2}$ & 1.02 & - & 1.34 & 11.8 & 0.19 & $1.32 \times 10^{-2}$ & 2.19 & $5.42 \times 10^{-2}$ & $2.89 \times 10^{-3}$ & 221.00 & 103.00 & $2.16 \times 10^{-3}$ \\
\hline \multirow{3}{*}{ RfD } & RfDing & 0.14 & $3.00 \times 10^{-3}$ & $2.00 \times 10^{-2}$ & $1.00 \times 10^{-3}$ & - & 0.14 & $2.00 \times 10^{-2 c}$ & $3.70 \times 10^{-2} \mathrm{~b}$ & 0.30 & $3.50 \times 10^{-3} \mathrm{~b}$ & 0.20 & 0.60 & $3.00 \times 10^{-4}$ & $3.00 \times 10^{-4 \mathrm{~d}}$ & $7.00 \times 10^{-3 c} \mathrm{c}$ \\
\hline & RfDinh & $5.00 \times 10^{-5}$ & $2.86 \times 10^{-5} \mathrm{a}$ & $2.06 \times 10^{-2 b}$ & $1.00 \times 10^{-3 b}$ & - & $5.00 \times 10^{-5}$ & $5.71 \times 10^{-6 c}$ & $4.02 \times 10^{-2} \mathrm{~b}$ & $0.30^{\mathrm{b}}$ & $3.52 \times 10^{-3} \mathrm{~b}$ & $1.43 \times 10^{-4} \mathrm{c}$ & & - & $8.57 \times 10^{-5} \mathrm{~d}$ & \\
\hline & RfDderm & $1.84 \times 10^{-3} \mathrm{c}$ & $2.50 \times 10^{-4 \mathrm{~b}}$ & $1.00 \times 10^{-3} \mathrm{~b}$ & $5.00 \times 10^{-5 b}$ & - & - & $1.60 \times 10^{-2 c}$ & $1.90 \times 10^{-3} \mathrm{~b}$ & $6.00 \times 10^{-2}$ & $5.25 \times 10^{-4 \mathrm{~b}}$ & $4.90 \times 10^{-3} \mathrm{c}$ & - & $3.00 \times 10^{-4}$ & $2.1 \times 10^{-6 \mathrm{~d}}$ & $9.00 \times 10^{-3}$ \\
\hline
\end{tabular}




\subsection{Assessment of Carcinogenic Health Risk}

The results for $\mathrm{HQ}$ and $\mathrm{HI}$ are listed in Table 6. Both adults and children followed a similar trend for $\mathrm{HQ}$ for all elements: $\mathrm{HQ}_{\mathrm{ing}}>\mathrm{HQ}_{\mathrm{derm}}>\mathrm{HQ}_{\text {inh }}$ except for $\mathrm{Mn}$ which followed $\mathrm{HQ}_{\text {inh }}>\mathrm{HQ}_{\mathrm{derm}}>$ $\mathrm{HQ}_{\text {ing, }}$, and Co which followed $\mathrm{HQ}_{\text {inh }}>\mathrm{HQ}_{\text {ing }}>\mathrm{HQ}_{\text {derm }}$. The $\mathrm{HQ}_{\text {ing }}$ values of $\mathrm{Co}$ (11.7), $\mathrm{Hg}$ (7.93), $\mathrm{Pb}$ (2.13), As (219), and the $\mathrm{HQ}_{\text {derm }}$ values of $\mathrm{As}$ (1.7), $\mathrm{Hg}$ (94), and $\mathrm{HQ}_{\text {inh }}$ value of $\mathrm{Mg}$ (1.33) were beyond 1 in the cases of children. The HQ values for all elements were all below 1 except $\mathrm{Hg}$ in the case of adults related to the ingestion pathway. It was found that the HI was approximately 10 times higher in children than adults; therefore, the elements of $\mathrm{Co}, \mathrm{Hg}, \mathrm{Pb}$, and $\mathrm{As}$ in road dust had adverse health effects in the children group, while it existed in the $\mathrm{Hg}$ for adult ingestion.

\subsection{Assessment of Cancer Risk}

ECRs for carcinogenic risk via the inhalation pathway were calculated, and the results are shown in Figure 5. According to the IRIS, the ECRs for $\mathrm{Cr}, \mathrm{Ni}, \mathrm{Cd}, \mathrm{Pb}$ and As were calculated in this study as were two additional forms of chromium persisting $\mathrm{Cr}$ (III) and $\mathrm{Cr}$ (VI). Only $\mathrm{Cr}$ (VI) has been established as carcinogenic. The value of $\mathrm{Cr}(\mathrm{VI})$ was used for calculating the carcinogenic health risk and was taken as one-seventh of the total mass of chromium in road dust since the ratio of $\mathrm{Cr}(\mathrm{VI})$ to Cr (III) is about 1:6 [34,47].

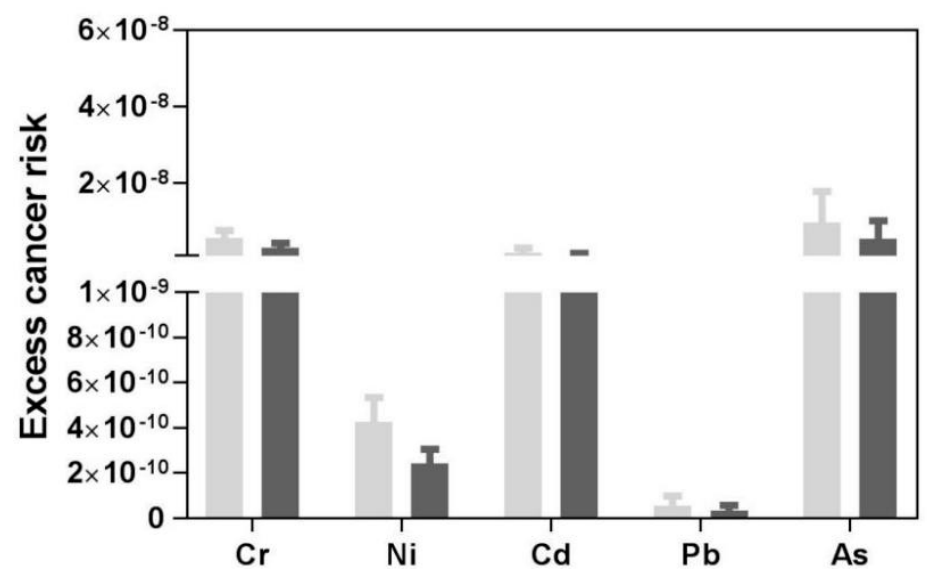

Figure 5. Excess Cancer Risk (ECR) of carcinogenic elements in road dust.

The trend of ECR was similar in both adults and children: $\mathrm{As}>\mathrm{Cr}(\mathrm{VI})>\mathrm{Cd}>\mathrm{Ni}>\mathrm{Pb}$. The highest ECR for As related to adult inhalation was $2.24 \times 10^{-8}$, which indicated that the value was under a permissible limit. Since the value was under the range limit of $10^{-6}$, contamination did not produce a serious carcinogenic risk.

\section{Conclusions}

The concentrations of 16 elements were divided into two groups: major and trace elements. Major elements are mainly from the Earth's crust, and levels were lower than the background values, while the trace elements (except $\mathrm{Mn}$ and V) which could stem from anthropogenic sources were the opposite. The contamination level assessment was made by using the pollution indices, $\mathrm{I}_{\text {geo, }}$ and EF. The results showed a wide range of values for different elements. $\mathrm{Mn}, \mathrm{Cr}, \mathrm{Fe}, \mathrm{Mg}, \mathrm{Al}, \mathrm{Ba}, \mathrm{Sr}$, As, and $\mathrm{V}$ all exhibited non-contamination. $\mathrm{Ni}, \mathrm{Co}, \mathrm{Cu}, \mathrm{Zn}$, and $\mathrm{Pb}$ exhibited moderate contamination, and $\mathrm{Hg}$ exhibited extreme contamination. The $\mathrm{EF}$ results showed that the $\mathrm{EF}$ values exhibited a decreasing trend: $\mathrm{Cd}>\mathrm{Hg}>\mathrm{As}>\mathrm{Pb}>\mathrm{Cu}>\mathrm{Co}>\mathrm{Zn}>\mathrm{Ni}>\mathrm{Cr}>\mathrm{V}>\mathrm{Mn}>\mathrm{Mg}>\mathrm{Fe}>\mathrm{Sr}>\mathrm{Ba}$. Cd, As, and $\mathrm{Hg}$ exhibited extremely high enrichment. $\mathrm{Co}, \mathrm{Cu}, \mathrm{Zn}$, and $\mathrm{Pb}$ exhibited very high enrichment. Moreover, other elements exhibited significant enrichment. 
The ingestion exposure was the highest for both adults and children, followed by dermal contact and inhalation. It showed the same decreasing trend for adults and children except for $\mathrm{Mn}$ and $\mathrm{Co}$. The health risk analysis showed that $\mathrm{Co}, \mathrm{Hg}, \mathrm{Pb}$, and $\mathrm{As} \mathrm{had} \mathrm{the} \mathrm{potential} \mathrm{to} \mathrm{cause}$ non-carcinogenic risks in children. In contrast, the values for adults were well within the safe limit, which is approximately one-tenth that of children. According to the calculations of carcinogenic risk, the trend of ECR for carcinogenic factors was similar for both adults and children: As $>\mathrm{Cr}(\mathrm{VI})>\mathrm{Cd}$ $>\mathrm{Ni}>\mathrm{Pb}$. The total ECRs were found to be under the adequate level for both adult and children. Although the results indicated no symbolic carcinogenic risk, people must pay more attention to the trace elements in road dust.

Author Contributions: W.H. and J.T. conceived of the study and conducted preliminary research to design the survey. J.B. designed the data collection and analysis methodology; S.S. collected the samples and make the experiment; T.S. carried out the analysis. N.L. wrote the manuscript from results to conclusions. All authors contributed to the research study and producing the final manuscript.

Funding: This study was supported by the National Natural Science Foundation of China (NSFC) (Grant No. 51508224), the Natural Science Foundation of Jilin Province (Grant No. 20140520148JH) and the China Scholar Council.

Acknowledgments: The authors would like to acknowledge the following students for assisting in data collection and recruitment for the survey: Mengnan Shen, Chunyu Kang, Xiaoxu Zhang, Yongli Ji.

Conflicts of Interest: The authors declare no conflict of interest.

\section{References}

1. Wu, H.; Zhang, Y.F.; Han, S.Q.; Wu, J.H.; Bi, X.H.; Shi, G.L.; Wang, J.; Yao, Q.; Cai, Z.Y.; Liu, J.L.; et al. Vertical characteristics of PM2.5 during the heating season in Tianjin, China. Sci. Total Environ. 2015, 523, 152-160. [CrossRef] [PubMed]

2. Zhang, X.; Wang, L.; Wang, W.; Cao, D.; Wang, X.; Ye, D. Long-term trend and spatiotemporal variations of haze over China by satellite observations from 1979 to 2013. Atmos. Environ. 2015, 119, 362-373. [CrossRef]

3. Chen, Y.; Schleicher, N.; Cen, K.; Liu, X.; Yu, Y.; Zibat, V.; Dietze, V.; Fricker, M.; Kaminski, U.; Chen, Y.; et al. Evaluation of impact factors on PM2.5 based on long-term chemical components analyses in the megacity Beijing, China. Chemosphere 2016, 155, 234-242. [CrossRef] [PubMed]

4. Zheng, Y.; Che, H.; Zhao, T.; Zhao, H.; Gui, K.; Sun, T.; An, L.; Yu, J.; Liu, C.; Jiang, Y.; et al. Aerosol optical properties observation and its relationship to meteorological conditions and emission during the Chinese National Day and Spring Festival holiday in Beijing. Atmos. Res. 2017, 197, 188-200. [CrossRef]

5. Schladitz, A.; Leníček, J.; Beneš, I.; Kováč, M.; Skorkovský, J.; Soukup, A.; Jandlová, J.; Poulain, L.; Plachá, H.; Löschau, G.; et al. Air quality in the German-Czech border region: A focus on harmful fractions of PM and ultrafine particles. Atmos. Environ. 2015, 122, 236-249. [CrossRef]

6. Mbengue, S.; Alleman, L.Y.; Flament, P. Metal-bearing fine particle sources in a coastal industrialized environment. Atmos. Res. 2017, 183, 202-211. [CrossRef]

7. Samiksha, S.; Sunder Raman, R.; Nirmalkar, J.; Kumar, S.; Sirvaiya, R. PM10 and PM2.5 chemical source profiles with optical attenuation and health risk indicators of paved and unpaved road dust in Bhopal, India. Environ. Pollut. 2017, 222, 477-485. [CrossRef] [PubMed]

8. Kong, S.; Li, X.; Li, L.; Yin, Y.; Chen, K.; Yuan, L.; Zhang, Y.; Shan, Y.; Ji, Y. Variation of polycyclic aromatic hydrocarbons in atmospheric PM2.5 during winter haze period around 2014 Chinese Spring Festival at Nanjing: Insights of source changes, air mass direction and firework particle injection. Sci. Total Environ. 2015, 520, 59-72. [CrossRef] [PubMed]

9. Mulder, M.D.; Heil, A.; Kukučka, P.; Kuta, J.; Přibylová, P.; Prokeš, R.; Lammel, G. Reprint of: Long-range atmospheric transport of PAHs, PCBs and PBDEs to the central and eastern Mediterranean and changes of PCB and PBDE congener patterns in summer 2010. Atmos. Environ. 2015, 121, 66-74. [CrossRef]

10. Soltani, N.; Keshavarzi, B.; Moore, F.; Tavakol, T.; Lahijanzadeh, A.R.; Jaafarzadeh, N.; Kermani, M. Ecological and human health hazards of heavy metals and polycyclic aromatic hydrocarbons (PAHs) in road dust of Isfahan metropolis, Iran. Sci. Total Environ. 2015, 505, 712-723. [CrossRef] [PubMed] 
11. Ali, M.U.; Liu, G.; Yousaf, B.; Abbas, Q.; Ullah, H.; Munir, M.A.M.; Fu, B. Pollution characteristics and human health risks of potentially (eco)toxic elements (PTEs) in road dust from metropolitan area of Hefei, China. Chemosphere 2017, 181, 111-121. [CrossRef] [PubMed]

12. Shi, G.; Chen, Z.; Bi, C.; Wang, L.; Teng, J.; Li, Y.; Xu, S. A comparative study of health risk of potentially toxic metals in urban and suburban road dust in the most populated city of China. Atmos. Environ. 2011, 45, 764-771. [CrossRef]

13. Gunawardana, C.; Egodawatta, P.; Goonetilleke, A. Role of particle size and composition in metal adsorption by solids deposited on urban road surfaces. Environ. Pollut. 2014, 184, 44-53. [CrossRef] [PubMed]

14. Bourliva, A.; Papadopoulou, L.; Aidona, E. Study of road dust magnetic phases as the main carrier of potentially harmful trace elements. Sci. Total Environ. 2016, 553, 380-391. [CrossRef] [PubMed]

15. Huang, J.; Li, F.; Zeng, G.; Liu, W.; Huang, X.; Xiao, Z.; Wu, H.; Gu, Y.; Li, X.; He, X.; et al. Integrating hierarchical bioavailability and population distribution into potential eco-risk assessment of heavy metals in road dust: A case study in Xiandao District, Changsha city, China. Sci. Total Environ. 2016, 541, 969-976. [CrossRef] [PubMed]

16. Liu, E.; Yan, T.; Birch, G.; Zhu, Y. Pollution and health risk of potentially toxic metals in urban road dust in Nanjing, a mega-city of China. Sci. Total Environ. 2014, 476-477, 522-531. [CrossRef] [PubMed]

17. Keshavarzi, B.; Tazarvi, Z.; Rajabzadeh, M.A.; Najmeddin, A. Chemical speciation, human health risk assessment and pollution level of selected heavy metals in urban street dust of Shiraz, Iran. Atmos. Environ. 2015, 119, 1-10. [CrossRef]

18. Olawoyin, R.; Schweitzer, L.; Zhang, K.; Okareh, O.; Slates, K. Index analysis and human health risk model application for evaluating ambient air-heavy metal contamination in Chemical Valley Sarnia. Ecotoxicol. Environ. Safe. 2017, 148, 72-81. [CrossRef] [PubMed]

19. Sun, J.; Hu, G.; Yu, R.; Lin, C.; Wang, X.; Huang, Y. Human health risk assessment and source analysis of metals in soils along the G324 Roadside, China, by Pb and Sr isotopic tracing. Geoderma 2017, 305, $293-304$. [CrossRef]

20. Wang, C.; Zhou, S.; Song, J.; Wu, S. Human health risks of polycyclic aromatic hydrocarbons in the urban soils of Nanjing, China. Sci. Total Environ. 2018, 612, 750-757. [CrossRef] [PubMed]

21. Mohmand, J.; Eqani, S.A.M.A.S.; Fasola, M.; Alamdar, A.; Mustafa, I.; Ali, N.; Liu, L.; Peng, S.; Shen, H. Human exposure to toxic metals via contaminated dust: Bio-accumulation trends and their potential risk estimation. Chemosphere 2015, 132, 142-151. [CrossRef] [PubMed]

22. Izhar, S.; Goel, A.; Chakraborty, A.; Gupta, T. Annual trends in occurrence of submicron particles in ambient air and health risk posed by particle bound metals. Chemosphere 2016, 146, 582-590. [CrossRef] [PubMed]

23. Gope, M.; Masto, R.E.; George, J.; Hoque, R.R.; Balachandran, S. Bioavailability and health risk of some potentially toxic elements $(\mathrm{Cd}, \mathrm{Cu}, \mathrm{Pb}$ and $\mathrm{Zn})$ in street dust of Asansol, India. Ecotoxicol. Environ. Safe. 2017, 138, 231-241. [CrossRef] [PubMed]

24. Tang, Z.; Chai, M.; Cheng, J.; Jin, J.; Yang, Y.; Nie, Z.; Huang, Q.; Li, Y. Contamination and health risks of heavy metals in street dust from a coal-mining city in eastern China. Ecotoxicol. Environ. Saf. 2017, 138, 83-91. [CrossRef] [PubMed]

25. Kim, H.S.; Kim, Y.J.; Seo, Y.R. An Overview of Carcinogenic Heavy Metal: Molecular Toxicity Mechanism and Prevention. Asian Pac. J. Cancer Prev. 2015, 20, 232-240. [CrossRef] [PubMed]

26. Yang, Z.; Lu, W.; Long, Y.; Bao, X.; Yang, Q. Assessment of heavy metals contamination in urban topsoil from Changchun City, China. J. Geochem. Explor. 2011, 108, 27-38. [CrossRef]

27. Tang, R.L.; Ma, K.M.; Zhang, Y.X.; Mao, Q.Z. The spatial characteristics and pollution levels of metals in urban road dust of Beijing, China. Appl. Geochem. 2013, 35, 88-98. [CrossRef]

28. Zhang, Y.; Hu, X.N.; Yu, T. Distribution and risk assessment of metals in sediments from Taihu lake, Chins using multivariate statistics and multiple tools. Bull. Environ. Contam. Toxicol. 2012, 89, 1009-1015. [CrossRef] [PubMed]

29. Lu, X.W.; Wang, L.J.; Lei, K.; Huang, J.; Zhai, Y.X. Contamination assessment of copper, lead, zinc, manganese and nickel in street dust of Baoji, NW China. J. Hazard. Mater. 2009, 161, 1058-1062. [CrossRef] [PubMed]

30. US EPA (U.S. Environmental Protection Agency). Framework for Human Health Risk Assessment to Inform Decision Making; EPA/100/R-14/001; Risk Assessment Forum, US EPA: Washington, DC, USA, 2014.

31. US EPA (U.S. Environmental Protection Agency). Guidelines for Exposure Assessment; EPA/600/Z-92/001; Risk Assessment Forum, US EPA: Washington, DC, USA, May 1992. 
32. US EPA (U.S. Environmental Protection Agency). Risk Assessment Guidance for Superfund: Volume I Human Health Evaluation Manual, Part F, Supplemental Guidance for Inhalation Risk Assessment; Office of Emergency and Remedial Response, US EPA: Washington, DC, USA, January 2009.

33. US EPA (U.S. Environmental Protection Agency). Risk Assessment Guidance for Superfund: Volume III-Part A, Process for Conducting Probabilistic Risk Assessment; Office of Emergency and Remedial Response, US EPA: Washington, DC, USA, December 2001.

34. U.S. EPA (U.S. Environmental Protection Agency). Risk Assessment Guidance for Superfund Volume I: Human Health Evaluation Manual (Part E, Supplemental Guidance for Dermal Risk Assessment); Office of Superfund Remediation and Technology Innovation: Washington, DC, USA, 2004.

35. Wester, R.C.; Maibach, H.I.; Sedik, L.; Melendres, J.; Wade, M. Percutaneous Absorption of PCBs from Soil: In Vivo Rhesus Monkey, In Vitro Human Skin, and Binding to Powered Human Stratum Corneum. J. Toxicol. Environ. Health 1993, 39, 375-382. [CrossRef] [PubMed]

36. Wester, R.C.; Maibach, H.I.; Sedik, L.; Melendres, J.; Wade, M.; DeZio, S. Percutaneous Absorption of Pentachlorophenol from Soil. Fund. Appl. Toxicol. 1993, 20, 68-71. [CrossRef]

37. IRIS (Integrated Risk Assessment System). United States Environmental Protection Agency. 1995. Available online: www.epa.gov/IRIS/ (accessed on 15 April 2018).

38. CNEMC (China National Environmental Monitoring Centre). The Soil Background Value in China; China Environmental Science Press: Beijing, China, 1990.

39. Li, H.M.; Qian, X.; Hu, W.; Wang, Y.L.; Gao, H.L. Chemical speciation and human health risk of trace metals in urban street dusts from a metropolitan city, Nanjing, SE China. Sci. Total Environ. 2013, 456-457, $212-221$. [CrossRef] [PubMed]

40. Trujillo-González, J.M.; Torres-Mora, M.A.; Keesstra, S.; Brevik, E.C.; Jiménez-Ballesta, R. Heavy metal accumulation related to population density in road dust samples taken from urban sites under different land uses. Sci. Total Environ. 2016, 553, 636-642. [CrossRef] [PubMed]

41. Azmat, Z.; Muhammad, Z.H.; Riffat, N.M.; Zulkifl, A. Enrichment and geo-accumulation of heavy metals and risk assessment of sediments of the Kurang Nallah-Feeding tributary of the Rawal Lake Reservoir, Pakistan. Sci. Total Environ. 2014, 470-471, 925-933.

42. Han, Y.; Cao, J.; Posmentier, E.S.; Fung, K.; Tian, H.; An, Z. Particulate-associated potentially harmful elements in urban road dusts in Xi'an, China. Appl. Geochem. 2008, 23, 835-845. [CrossRef]

43. Men, C.; Liu, R.; Xu, F.; Wang, Q.; Guo, L.; Shen, Z. Pollution characteristics, risk assessment, and source apportionment of heavy metals in road dust in Beijing, China. Sci. Total Environ. 2018, 612, 138-147. [CrossRef] [PubMed]

44. Kamani, H.; Ashrafi, S.D.; Isazadeh, S.; Jaafari, J.; Hoseini, M.; Mostafapour, F.K.; Bazrafshan, E.; Nazmara, S.A.; Mahvi, H.A. Heavy Metal Contamination in Street Dusts with Various Land Uses in Zahedan, Iran. Bull. Environ. Contam. Toxicol. 2015, 94, 382-386. [CrossRef] [PubMed]

45. Pan, H.; Lu, X.; Lei, K.A. comprehensive analysis of heavy metals in urban road dust of Xi'an, China: Contamination, source apportionment and spatial distribution. Sci. Total Environ. 2017, 609, 1361-1369. [CrossRef] [PubMed]

46. Gao, P.; Lei, T.; Jia, L.; Song, Y.; Lin, N.; Du, Y.; Feng, Y.; Zhang, Z.; Cui, F. Exposure and health risk assessment of PM2.5-bound trace metals during winter in university campus in Northeast China. Sci. Total Environ. 2017, 576, 628-636. [CrossRef] [PubMed]

47. U.S. EPA (U.S. Environmental Protection Agency). Risk Assessment Guidance for Superfund: Volume I Human Health Evaluation Manual, Part B, Development of Risk-based Preliminary Remediation Goals; US EPA: Washington, DC, USA, December 1991.

(C) 2018 by the authors. Licensee MDPI, Basel, Switzerland. This article is an open access article distributed under the terms and conditions of the Creative Commons Attribution (CC BY) license (http:/ / creativecommons.org/licenses/by/4.0/). 